\title{
Mediating mind-sets: the Cerro Khapía Landscape Reserve in the Peruvian Andes
}

\author{
Domenico Branca, Andreas Haller, Boris Blanco-Gallegos \& Vicente Alanoca-Arocutipa
}

Keywords: land use, conflict, ontology, worldview, Aymara

\section{Abstract}

The creation of protected mountain areas is often preceded by conflicts over access and use of natural resources. The case of the Cerro Khapía in the Peruvian Andes, however, points to mountains as not just nature but also culture. More than a decade ago, different ontologies and opposing views on mountains led to protests of the Aymara people against the exploitation of Cerro Khapía by a Canadian mining company, mainly because the mountain is the local Aymara's apu or tutelary god. Today, Cerro Khapía is temporarily protected as a Reserved Zone and on track to become a permanently protected area. Moreover, it is a case in point of the importance of questioning one's own ontological viewpoint and mediating different mind-sets.
Profile

Protected area

Cerro Khapía Reserved

Zone

Mountain range

Peruvian Andes

\section{Introduction}

Socio-environmental conflicts usually do not fit into common imaginaries of peaceful protected mountain areas, wild sites of harmony between nature and culture. However, across the globe, both conflicts and conservation are often closely interwoven processes (e. g., Badola \& Hussain 2003; Braun et al. 2018; Haller \& Córdova-Aguilar 2018; Thomas \& Middleton 2003). Since the 1990s, an exponential increase in socio-environmental conflicts has been observed on a global level, especially in the Global South. For instance, there are currently 683 active conflicts in South America according to the Atlas of Environmental Justice (EJA), 96 of them in Peru alone. Since 2010, the Department of Puno, mainly situated in the high Andes, has occupied top positions in the "ranking of regions with the highest number of social conflicts" (Angulo 2015: 18; see Pinto Herrera 2013). These conflicts are usually related to the (planned) extraction of raw materials for export (Gudynas 2009), one of the most important sources of income for the Peruvian economy. The establishment of protected areas in former sites of socio-ecological conflicts can be a strategy to solve problems that originate from conflicting understandings of nature and culture (see Gade 1999).

The case of the Zona Reservada Reserva Paisajistica del Cerro Khapia (Reserved Zone of the Cerro Khapía Landscape Reserve), is a perfect case in point. It concerns a socio-environmental conflict popularly known in Peru as the aymarazo (Quiñones 2013). This protest began a decade ago, in April 2011, against exploratory operations in the area of Kelluyo and Huacullani districts, for which the state had granted a con- cession $^{1}$ (Zevallos-Yana 2020) to the Canadian mining company Bear Creek, already active in other regions of Peru, on 29 November 2007 (Supreme Decree no. 083-2007-EM; Anonymous 2007) for the extraction of silver. There was local opposition from the beginning, but it intensified from 2011 when the company was about to start operations in the area (Pinto Herrera 2013). A large part of the local population and several grassroots organizations pointed out the risk of environmental contamination and demanded: (1) a retraction of the mining concession; and (2) the protection of the Cerro Khapía, a tutelary mountain or apu threatened by the mining concession (Eschenhagen \& Baca 2014).

Our aim is to show how the creation of the Reserved Zone of the Cerro Khapía Landscape Reserve in 2011 (Supreme Decree no. 008-2011-MINAM; Anonymous 2011a) is the result of an ontological struggle (Blaser 2019) by local indigenous communities and, therefore, its designation is a relevant precedent for the recognition of other worldviews all over the globe; worldviews that do not conceptualize land primarily as a resource to be exploited (de la Cadena 2015; Escobar 2015). From a methodological point of view, this report presents outcomes of a long-term ethnographic research, started in 2013 in the Andean region of Puno, Peru. Data were collected through a set of heterogeneous techniques, ranging from participant observation at events (e.g., protests), to in-depth interviews with key actors, to the analysis of newspaper articles and grey literature.

The mining concession (concesion minera) is issued by the state at the request of the applicant, and the state, as administrator of the natural resources, grants the applicant certain rights and obligations for the use of the natural resources; however, it must be made clear that the mining concession does not grant its holder ownership of the land or surface property (Zevallos-Yana 2020: 61; translation by the authors). 


\section{Cerro Khapía: a mountain between conflict and conservation}

Located on the Peruvian Altiplano or Collao plateau $\left(16^{\circ} 19^{\prime} 52^{\prime \prime} \mathrm{S}\right.$ and $69^{\circ} 08^{\prime} 32^{\prime \prime} \mathrm{O}$, approx. $3800 \mathrm{~m}$ a.s.l.), in the southern part of the Province of Chucuito, the Cerro Khapía Landscape Reserve covers an area of 18313.79 hectares. According to Pulgar Vidal's (1946) model, it is situated in the Suni altitudinal zone and belongs to the catchment area of Lake Titicaca. The area also features wetlands from which some rivers originate. Cerro Khapía is the highest mountain in the south of the Department of Puno, stretching from the Suni over the entire Puna region, reaching the boundary with the Janca altitudinal zone at 4800 m.a.s.l. Hence, it stands out impressively from the generally flat Collao plateau.

The mountain increasingly attracts visitors keen on trekking or mountaineering and enjoying the Andean landscape (Figure 1). At the top of Cerro Khapía, there is a lagoon called Warawarani, possibly the crater of the now inactive volcano. There are various forms of endemic fauna and, regarding the flora, there are relicts of queñual trees (Polylepis spp.). Finally, the (transitional) protected area category Reserved Zone of Peru's Servicio Nacional de Áreas Naturales Protegidas (SERNANP) recognizes the right of the neighbouring farming communities to own and use the water resources in accordance with local cultural practices. From an ethno-linguistic point of view, most of the local population is Aymara-speaking, engaged in agriculture and small-scale trade for their livelihood (Alanoca-Arocutipa 2013; Branca 2017). This is why Cerro Khapía is not only an important natural landmark: for the indigenous population of the Department of Puno, it is an apu, that is, a sacred mountain with which these people have a relationship of reciprocity and even kinship. For instance, in 2016 a new species of beetle was discovered in the area and called Trecbisibus apukhapiensis sp.n., after the Khapía's ари (Ruiz-Tapiador \& Delgado 2016), underlining the connection between nature and culture. In this sense, strictly separating natural and cultural dimensions of the mountain is not an option for the local communities. From the Aymara point of view, the natural, in the sense of non-indigenous modern ontology, is neither inert nor static, but alive and integrated through socioeconomic, political and cultural relations with human and non-human beings. Recognizing these facts, the area was declared a Reserved Zone by the Peruvian State on 28 May 2011, amid severe conflicts between different social actors: the state, the Canadian transnational company Bear Creek, and the farming communities of the area.

\section{Reasons for the conflict}

On 10 May 2011, farming communities in the south of Puno began an indefinite strike against the

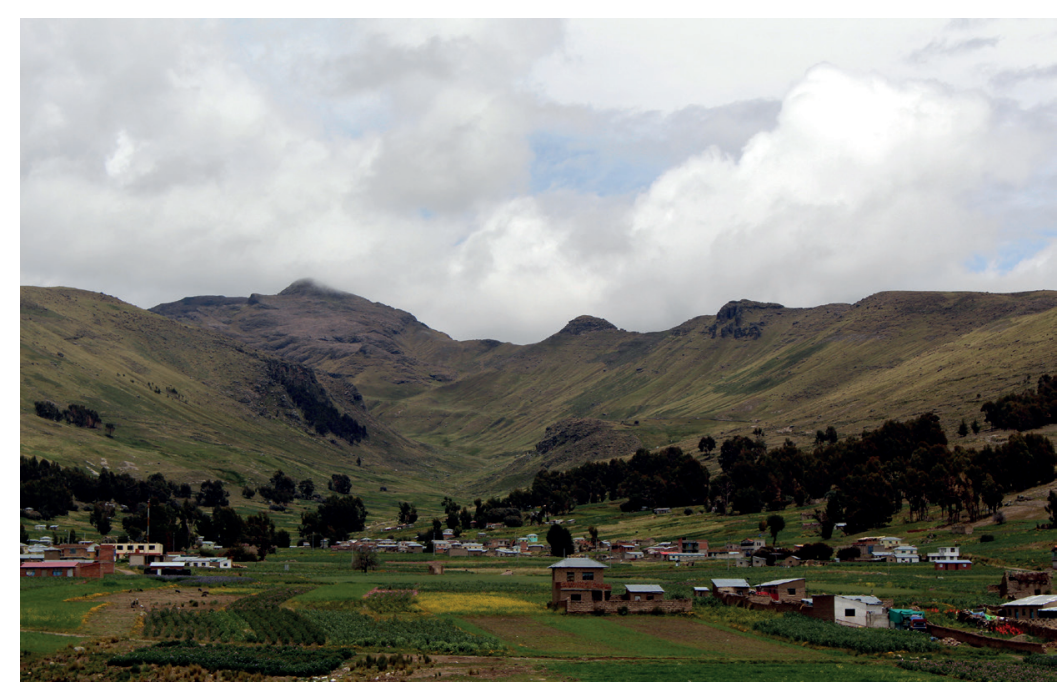

Figure 1 - The Cerro Khapia Landscape Reserve. (C) Boris Blanco-Gallegos (2021)

exploration of an area in the district of Kelluyo for the extraction of silver by the Canadian transnational Bear Creek corporation, which, according to the protesters, would contaminate the natural resources of the area. The strike, led by the Front for the Defence of Environmental Resources in the Southern Zone of Puno, led by Walter Aduviri, paralyzed the entire south of the department and interrupted communications with neighbouring Bolivia. The strike won the protesters a first victory, with the archaeological cultural landscape of Cerro Khapía being declared a National Cultural Heritage Site on 20 May 2011 (Vice-Ministerial Resolution no. 589-2011-VMPCICMC; Anonymous 2011b). Despite this, the protesters aimed at the retraction of all concessions and, for this reason, they continued the strike. On 23 May, more than 5000 residents from the south arrived in Puno, demanding the termination of the Santa Ana mining project and the development of agricultural projects in its place. On the afternoon of 26 May, the city of Puno was the scene of heavy clashes between the police and various groups of demonstrators from the south of the region. There was violence and attacks on bank branches, state-owned vehicles and, in Puno, the premises of the tax offices (SUNAT) and the National Comptroller's Office (Contraloría General de la República). Similar disturbances also occurred in the town of Desaguadero, where the customs office was set on fire. In the days that followed, the protest subsided, but echoes range through the following years, also with the anti-mining protests still strong in the region. Bear Creek, therefore, never began operations on the Santa Ana concession because of the opposition of the local population. For this reason, between 2014 and 2017, the company appealed to international arbitration under the Canada-Peru Free Trade Agreement, which was heard at the International Centre for Settlement of Investment Disputes (ICSID) in Washington D.C. The Tribunal found in favour of 
Table 1 - Timeline of events that led to the renouncement of the Santa Ana mining concession by Bear Creek.

\begin{tabular}{|l|l|l|}
\hline Date & Event & Remark \\
\hline 29 November 2007 & Mining concession granted to Bear Creek & Supreme Decree no. 083-2007-EM (Anonymous 2007) \\
\hline 10 May 2011 & Beginning of peasant protests against mining activities & \\
\hline 20 May 2011 & $\begin{array}{l}\text { Declaration of the archaeological cultural landscape at } \\
\text { Cerro Khapía as a National Cultural Heritage }\end{array}$ & $\begin{array}{l}\text { Vice-Ministerial Resolution no. 589-201 1-VMPCIC-MC } \\
\text { (Anonymous 201 1b) }\end{array}$ \\
\hline 28 May 2011 & $\begin{array}{l}\text { Declaration of the whole Cerro Khapía as a Reserved } \\
\text { Zone }\end{array}$ & $\begin{array}{l}\text { Supreme Decree no. 008-201 1-MINAM (Anonymous } \\
\text { 201 1a) }\end{array}$ \\
\hline 13 November 2018 & Retraction of mining concessions by Bear Creek & \\
\hline
\end{tabular}

the corporation, which was awarded a compensation of approximately USD 30.4 million (Bear Creek s.a.). In 2018 several organizations presented a manifesto in defence of territories and natural resources and against the unjust criminalization of social protest and the collusion of the state with foreign capital (Anonymous 2018a). On 13 November 2018, the Bear Creek Mining Corporation retracted the mining concessions of the Santa Ana project and the Peruvian Geological Mining and Metallurgical Institute communicated that all concessions of the former Santa Ana project were terminated (Anonymous 2018b; Anonymous 2019; see Table 1).

\section{Mountains in Aymara ontology}

The local population's claims had to do with the retraction of any concessions, one of which would have affected the Cerro Khapía. To understand the scope of the conflict, it is useful to compare the perspective of former President García, specifically on the issue of the Cerro Khapía, and the Aymara anti-mining point of view.

"We have to] defeat the absurd, pantheistic ideologies that believe that the walls are gods and the air is god, in short, to go back to those primitive formulas of religiosity where they say 'Don't touch that hill because it's an apu and it's full of the millenarian spirit of I don't know what', right?' Well, if it comes to that, then let's not do anything, not even mining. [...] We go back to, let's say, this primitive animism, right? [...] If it is an environmental sanctuary, fine, but if it is a sanctuary because the souls of the ancestors are there, well... For me, the ancestors are surely in heaven, they are not there, and let those who now get their livelibood from an investment in those hills" (García 2011; translation by the authors).

García did not contemplate the possibility that the main demands of those opposing the mining company's operations included not just the total retraction of the concessions but also the demand to cancel the rights of another company, Patagonia SA, in the Cerro Khapía area (Quiñones 2013; Pinto Herrera 2013). Anti-mining positions usually underline the risk of environmental impacts, such as water and soil contamination, endangering the habitability of the site for people, plants and animals (Salas Carreño 2017; Sault 2018). Yet, to Aymara people the destruction of the mountain means not only the destruction of nature, but a complex and painful destruction of an ontological world.
While for García the souls of the dead live in paradise, the Aymara concept is different. Despite colonial attempts to impose the Christian tripartition of hell, purgatory, and paradise, whose closest translation into Aymara is manqha, aka and alaxa pacha, the transferability of these notions to indigenous Aymara contexts is difficult. Pacha is a polysemous term that in Aymara can include the dimensions of time and space: nayra pacha (literally, time / space eyes) can be translated as past, according to the idea of what the speaker knows and can legitimately refer to as having seen/experienced or heard from a reliable source. Similarly, aka pachana, formed from the adverb of place aka, here, by the root pacha- and the suffix -na indicating a state in place, defines space. Alaxa pacha, literally, the space / place above, is assimilated to the Christian idea of heaven and thus of paradise. But there is more than one pacha. For example, the jallu pacha, time / space of rain, indicates both the rainy period, roughly from $\mathrm{No}$ vember to April, and the space from which the rain originates, rain that infiltrates the earth allowing the cycle to continue.

Yet the earth is also the burial place of the deceased who, after a complex and articulated ritual of separation from humanity as a condition (Ventura et al. 2018), which lasts three years, are recomposed again in the elements of the landscape (Branca 2018), becoming, for example, uywiri - from uywaña, to raise, plus the suffix - $r$ i denoting the agent performing the action, spirits generally benevolent in comparison to the achachilas and awichas, literally grandfathers" and grandmothers, whose relationship with humanity is closely connected to forms of reciprocity functional to maintaining the pacha in a state of equilibrium. Marisol de la Cadena wrote: "to runakuna, [...] tirakuna are their names. More clearly, no separation exists between Ausangate [a Cusco apu] the word and Ausangate the earth-being; no meaning mediates between the name and the being" (de la Cadena 2015: 25). While for García the tutelary mountains or apus are primitive beliefs, for thousands of individuals they are a fundamental component of individual and group relations (Salas Carreño 2017). With the apus it is necessary to maintain a relationship of reciprocity and shared care, through a series of ritual practices that affect everyday life (Figure 2). Whenever it comes to the use of nature in the central Andes, culture should not be considered its opposite, and groups of different mind-sets might require careful mediation. 


\section{Outlook: landscape reserves and/or An- dean cosmo vision?}

Although existing now for more than a decade, the protected area categorization of the Cerro Khapía Landscape Reserve is still only transitional. As SERNANP (s.a.; translation by the authors) states,

"It]he establishment process [of a protected area] may go through a transitional Reserved Zone. Reserved Zones are those areas that meet the conditions to be considered as Natural Protected Areas, but require complementary studies to determine, among others, the area covered and the category that corresponds to them as such, as well as the viability of their management. In this sense, it is important to point out that unlike the definitive Natural Protected Areas, the Reserved Zones are not established in perpetuity [.]"

In the present case, the intention to categorize the Cerro Khapía as an official Landscape Reserve in future is expressed by its current name. In this context, however, one might reflect on the usefulness of applying the notion of landscape to a site of importance from an Andean worldview. While in present European thought the urban Renaissance idea of landscapes as aesthetic painted environment still prevails (alongside a naturalistic notion that defines landscapes as ecosystems), Andean indigenous perspectives conceptualize the environment more as mother (pacha mama), selected mountain environments as gods or apus. Furthermore, Sarmiento (2017) rightfully highlights the various forms of a sincretismo paisajista or landscape syncretism, amalgamating nature and culture in a framework that draws on different religions and both Iberian and Andean worldviews. Therefore planners, policy makers, and protected area managers should constantly question existing categories like landscape, such a simple and seemingly widely understood term, which, however, means very different things to very different people. Using the same words does not automatically mean speaking the same language. To carry out an appropriate categorization, especially for local mountain communities, the process of finding the right protected area category could take place within a participatory and transdisciplinary montological setting (Haller \& Branca 2020; Sarmiento 2020). Such an approach could help to mediate between mindsets and avoid more socio-environmental conflicts, making common imaginaries of peaceful protected mountain areas a reality.

\section{Acknowledgment}

Domenico Branca would like to thank the research project Ecofrictions of Anthropocene. Sustainability and Herigitisation in the Processes of Industrial Reconversion of the Italian Ministry of Education and Research (PRIN 2015-20155TYKCM-SH5, unit PI Dr. Franco Lai) for funding part of this research.

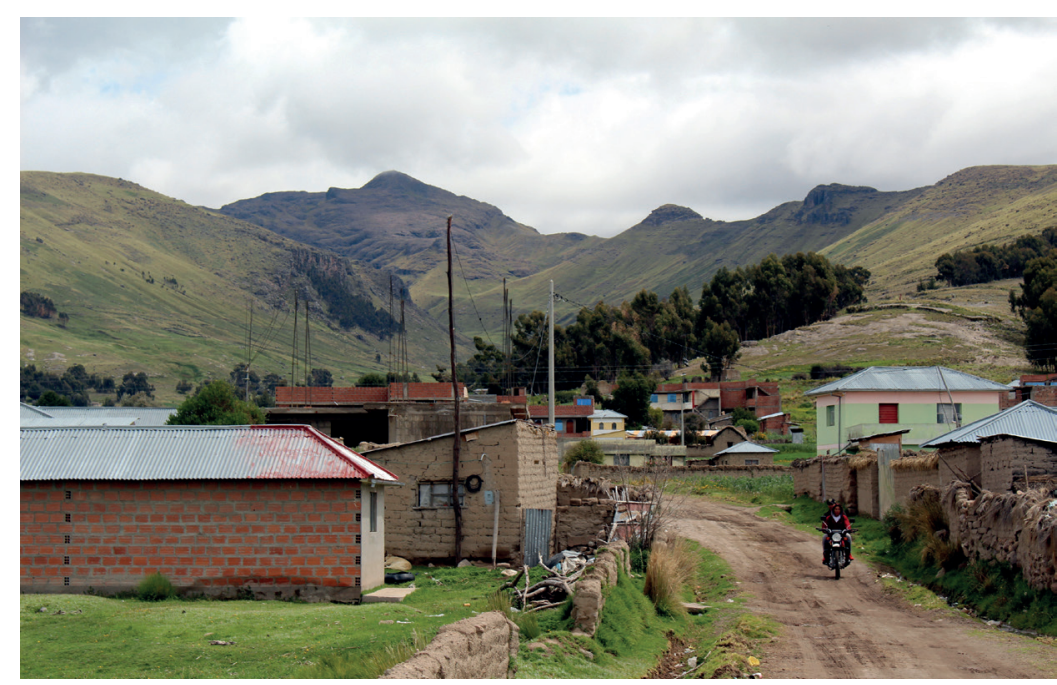

Figure 3 - The Aymara farming community of Choquechaca near the Cerro Khapia. (C) Boris Blanco-Gallegos (2021)

\section{References}

Alanoca-Arocutipa, V. 2013. Conflictos aimaras. Puno.

Angulo, M. 2015. Periodismo regional y conflictos sociales. Análisis de las opiniones de los diarios Correo y Los Andes de Puno (Perú) durante el conflicto social del 'Aimarazo' (2011). Campos 5 (1-2): 13-37. Bogotá. Doi: 10.15332/s2339-3688.2017.0001.01

Anonymous 2007. Autorizan a empresa minera a realizar actividades dentro de los cincuento kilómetros de zona de frontera: Decreto Supremo No 083-2007EM. El Peruano 29 November: 358511-358512. Lima.

Anonymous 2011a. Decreto Supremo que declara Zona Reservada "Reserva Paisajística Cerro Khapia" y dicta disposiciones para la protección de los recursos hídricos en las cabeceras de cuenca del Cerro Khapia: Decreto Supremo No 008-2011-MINAM. El Peruano 28 May: 443372-4463373. Lima.

Anonymous 2011b. Declaran patrimonio cultural de la Nación a monumento arqueológico prehispánico ubicado en el departamento de Puno: Resolución Viceministerial No 589-2011-VMPCIC-MC. El Peruano 20 May: 442834-442835. Lima.

Anonymous 2018a. Presentan manifiesto público que rechaza criminalización de la protesta. Available at: http:// web.archive.org/web/20180911182938/https:// www.servindi.org/actualidad-noticias/10/09/2018/ presentan-manifiesto-publico-en-rechazo-la-criminalizacion-de-la (accessed 16/04/2021)

Anonymous 2018b. Puno: Bear Creek renuncia a las concesiones mineras delproyecto Santa Ana. Available at: http:// web.archive.org/web/20190112052036/https:// www.servindi.org/actualidad-noticias/11/01/2019/ bear-creek-renuncia-las-concesiones-mineras-delproyecto-santa-ana (accessed 16/04/2021)

Anonymous 2019. Bear Creek, renuncia al proyecto minero Santa Ana. Available at: http://web.archive.org/ web/20210309155624/https://mineriaenergia.com/ 
bear-creek-renuncia-al-proyecto-minero-santa-ana/ (accessed 16/04/2021)

Badola, R. \& S.A. Hussain 2003. Conflict in Paradise: Women and Protected Areas in the Indian Himalayas. Mountain Research and Development 23(3): 234-237. Doi: $\quad$ 10.1659/0276-4741(2003)023[0234:CIP]2.0. $\mathrm{CO} ; 2$

Bear Creek. s.a. Santa Ana. Available at: http://web. archive.org/web/20201205153411/https://www. bearcreekmining.com/projects/santa-ana/ (accessed 16/04/2021)

Blaser, M. 2019. Reflexiones sobre la ontología política de los conflictos medioambientales. América Crítica 3(2): 63-79. Doi: 10.13125/americacritica/3991

Branca, D. 2017. Identidad aymara en el Perú. Nación, vivencia y narración. Lima.

Branca, D. 2018. Identidad, alteridad y el Día de los Muertos en el Altiplano aymara de Puno, Perú. Anales de Antropología 52(2): 141-155. Doi: 10.22201/ iia.24486221e.2018.2.63354

Braun, V., G. Bendler, A. Haller \& K. Heinrich 2018. Timelines of Tension: Trajectories of Protected-Area Creation in the Austrian Alps. Journal of Alpine Research | Revue de Géographie Alpine 106(4): 1-20. Doi: $10.4000 /$ rga.4711

De la Cadena, M. 2015. Earth Beings: Ecologies of Practice across Andean Worlds. Durham \& London.

Escobar, A. 2015. Territorios de diferencia: La ontología política de los "derechos al territorio". Cuadernos de Antropología Social 41: 25-38. Buenos Aires.

Eschenhagen, M.L. \& H. Baca 2014. Comunidades aymaras y la gran minería. Una mirada a los argumentos detrás del conflicto socioambiental en Puno, Perú. In: Göbel, B. \& A. Ulloa (eds.), Extractivismo minero en Colombia y en América Latina: 75-105. Berlin \& Bogotá.

Gade, D. 1999. Nature and Culture in the Andes. Madison.

García, A. 2011. Alan Garcia contra las ideologias absurdas panteistas. Available at: https://youtu. be/2Vf4WfS5t08 (accessed 01/20/2019).

Gudynas, E. 2009. Diez tesis urgentes sobre el nuevo extractivismo. Contextos y demandas bajo el progresismo sudamericano actual. In: Schuldt, J., A. Acosta, A. Barandiarán et al. (eds.), Extractivismo, política y sociedad: 379-410. Quito.

Haller, A. \& H. Córdova-Aguilar 2018. Urbanization and the advent of regional conservation: Huancayo and the Cordillera Huaytapallana, Peru. eco.mont - Journal on protected mountain research and management 10(2): 37-56. Doi: 10.1553/eco.mont-10-2s59

Haller, A. \& D. Branca 2020. Montología: una perspectiva de montaña hacia la investigación transdisciplinaria y el desarrollo sustentable. Revista de Investigaciones Altoandinas 22(4): 313-322. Doi: 10.18271/ ria. 2020.193

McDonell, E. 2015. The Co-Constitution of Neoliberalism, Extractive Industries, and Indigeneity: Anti-mining protests in Puno, Peru. The Extractive
Industries and Society 2(1): 112-123. Doi: 10.1016/j. exis.2014.10.002

Pinto Herrera, H. 2013. Conflicto minero en Santa Ana (Puno). Investigaciones Sociales 17(31): 207-220. Doi: 10.15381 /is.v17i31.7909

Pulgar Vidal, J. 1946. Historia y geografía del Perú. Las ocho regiones naturales del Perú. Lima.

Quiñones, P. 2013. Concesiones, participación y conflicto en Puno. El caso del proyecto minero Santa Ana. Los límites de la expansión minera en el Perú: 15-70. Lima.

Ruiz-Tapiador, I. \& P. Delgado 2016. Trechisibus apukhapiensis sp. n. (Coleoptera: Carabidae, Trechinae) from southeastern Andean mountains of Peru. Baltic Journal of Coleopterology 16(2): 97-104.

Salas Carreño, G. 2017. Mining and the living materiality of mountains in Andean societies. Journal of Material Culture 22(2): 133-150. Doi: $10.1177 / 1359183516679439$

Sarmiento, F. 2017. Transformación sincrética del paisaje rural en los Andes: una aplicación sinóptica de las geografías andinas de Axel Borsdorf. In: Sánchez, R., R. Hidalgo \& F. Arenas (eds.), Re-conociendo las geografías de América Latina y el Caribe: 35-54. Santiago de Chile.

Sarmiento, F. 2020. Montology manifesto: echoes towards a transdisciplinary science of mountains. Journal of Mountain Science 17: 2512-2527. Doi: 10.1007/ s11629-019-5536-2

Sault, N. 2018. Condors, waters, and mining: Heeding voices from Andean communities. Ethnobiology Letters 9(1): 13-29.

SERNANP. s.a. ¿Cómo se establece un ANP? Available at: https://web.archive.org/web/20210304134041/ https://www.sernanp.gob.pe/como_se_establecen (accessed 01/20/2019)

Thomas, L. \& J. Middleton 2003. Guidelines for Management Planning of Protected Areas. Gland, Switzerland and Cambridge, UK.

Ventura, M., J.L. Mateo \& M. Clua 2018. La humanidad: Antropología de un concepto. In: Ventura, M., J.L. Mateo \& M. Clua (eds.), Humanidad. Categoría o condición. Un viaje antropológico: 13-37. Barcelona.

Zevallos-Yana, J.F. 2020. Concesiones mineras, comunidades campesinas y conflictos sociales en la región de Puno. Revista de Derecho de la Universidad Nacional del Altiplano 5(1): 54-70. Doi: 10.47712/rd.2020. v5i1.55

\section{Authors}

\section{Domenico Branca}

received his $\mathrm{PhD}$ in Social Anthropology from the Autonomous University of Barcelona (Spain) and is currently a postdoctoral researcher at the Institute for Interdisciplinary Mountain Research of the Austrian Academy of Sciences in Innsbruck. His research focuses on the study of ethnic identities and urban and 
mountain anthropology and geography in the Peruvian Andes.

\section{Andreas Haller}

received his $\mathrm{PhD}$ in Geography from the University of Innsbruck (Austria) and is currently a postdoctoral researcher and principal investigator at the Institute for Interdisciplinary Mountain Research of the Austrian Academy of Sciences. His research interests include rural-urban interaction, urbanization, and landuse change in mountain environments.

\section{Boris Blanco-Gallegos}

received his BA in Anthropology from the Universidad Nacional del Altiplano de Puno (Peru). He is a researcher and former member of the Institute for the Studies of Andean Cultures (IDECA) in Puno (Peru). His main research is on the study of environmental social sciences and ethnoecology in the Peruvian Andes.

\section{Vicente Alanoca-Arocutipa}

received his $\mathrm{PhD}$ in History of Latin America from the Pablo de Olavide University of Seville (Spain) and is currently Professor of Anthropology at the Universidad Nacional del Altiplano de Puno (Peru). His main research interests are on the study of indigenous movements, critical thought, and environmental issues in the Peruvian Andes. 